\title{
INTERLENDING SERVICES IN TURKISH UNIVERSITY LIBRARIES
}

\author{
Yasar Tonta
}

The article begins with an overview of the current situation in Turkish university libraries, which were badly affected by the economic crisis of 1977-82. In 1982 the Higher Education Council (HEC) approved the centralization of university libraries, and HECDOC (HEC Documentation and International Literature Search Centre) was set up in order to develop a national collection of serials in support of university library collections. Up to now, interlending in Turkish university libraries has been largely neglected, not helped by a law which makes librarians personally responsible for all losses from their library. A survey of 28 university libraries has shown that current use of ILL services is not great, with the various libraries disagreeing in their attitudes to charging for ILL. HECDOC provides $55 \%$ of satisfied ILL requests and it is hoped that the creation of a union catalogue of serials, together with a standard photocopy request form, will increase this. Collection development in Turkish university libraries is seriously affected by declining budgets, rising literature costs and a shortage of hard currency. Resource sharing, including ILL, is seen as one way of solving these problems.

This paper describes the use made of interlending services provided by Turkish university libraries. A questionnaire was used to gather data on the numbers of national and international ILL transactions; the channels (mail, telex, telefax, etc) used for transmitting both requests and documents; union lists of serials; and the level of photocopying activity in university libraries.

Turkish university libraries

There are 28 universities in Turkey, all governed by a common law, namely the Higher Education Act. All but one (the University of Bilkent) are state-financed.

Teaching takes place in Turkish, except at the Middle East Technical University (METU), the Bosporus and the Bilkent Universities, where courses are given in English.

Including distance learning students there are over 370,000 people enrolled in higher education, and about 22,000 faculty members. In 1983 the number of students in higher education per 100,000 inhabitants was 701, a rather higher figure than for other developing countries. In the same year the total expenditure on education constituted 3.4 per cent of the gross national product (GNP). 1

\begin{abstract}
Yasar Tonta is a research assistant at the Department of Librarianship at Hacettepe University, Ankara, where he has been teaching since 1981. He holds an MA in librarianship from Hacertepe University and an MLib from the College of Librarianship Wales, and is currently working for a PhD. He has published numerous papers in the feld of librarianship and information studies. Mr Tonta is a member of the Turkish Information Society and is the Secretary General of the TLA's Ankara branch.
\end{abstract}

The majority of universities have decentralized libraries. Of these the University of the Aegean, which comprises 37 attached libraries, Universities of Dokuz Eylül (17), Istanbul and Selcuk (13 each) are the extreme cases. Each of these libraries was, before 1982, a separate entity controlled not by the Central Library but by the deans of the various faculties. The consequent non-standard acquisition and processing procedures resulted in a great deal of duplication and the use of a variety of different methods of cataloguing and classification.

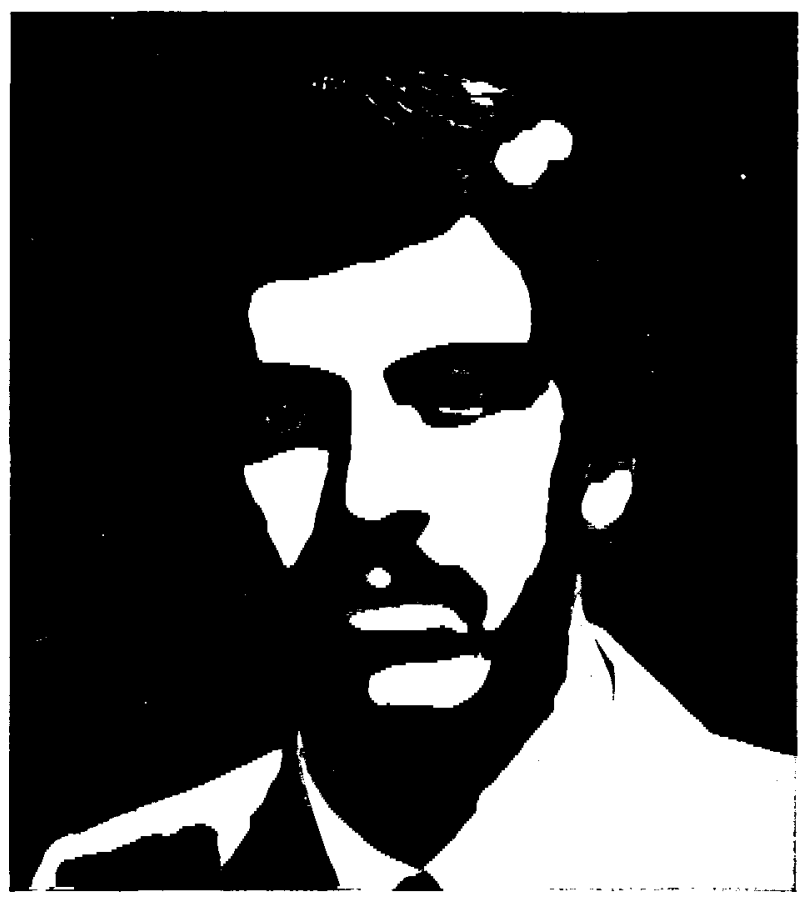


Economic difficulties severely affected the budgets of university libraries between 1977 and 1982. During that period Turkey faced one of the worst economic crises in its history. University libraries in particular suffered from very limited budgets. The problem was twofold. On the one hand, the dearth of hard currency was the nightmare of university librarians as the library resources required were mostly obtained from abroad. At the same time the price of books and journals from the US and other hard currency countries increased steadily with a yearly inflation rate of $25 \%-40 \%$. It was therefore almost impossible to buy anything other than essential items from abroad and even well-organized, centralized university libraries had to cancel many of their subscriptions to foreign serials.

It was decided that the centralization of university libraries would help to remedy these financial problems and in 1982 the Higher Education Council (HEC) approved the centralization of the administration of all libraries within a university, and the acquisition of all books and serials by the central library.

HECDOC (HEC Documentation and International Literature Search Centre) was established to develop a national collection of serials which would support university library collections, thereby obviating the need for each university to develop its own large collection. Instead university libraries would be able to spend their limited resources on the most heavily used serials and on purchasing more books. (Traditionally some $70 \%$ of their budgets have been devoted to serials. $)^{2}$ It was also felt that the creation of HECDOC would reduce the dependence of Turkish university libraries on foreign libraries. ${ }^{3}$ So far HECDOC has built up a collection of 10,000 serial titles and is aiming to increase this figure to 16,000 .

The library collections of individual universities range in size from hundreds of thousands of volumes, at the Universities of Istanbul, Hacettepe, Atatürk and METU, to a very limited number of volumes at newly established universities like Yüzüncü Yil, Inönü and Bilkent.

Likewise the number of current serial titles acquired by each university library shows a great deal of variation. For instance, the Universities of the Mediterranean and Inönü subscribe to less than 100 titles. Similarly, the number varies between 154 and 230 for the Universities of Cumburiyet, Erciyes, Ondokuz Mayis, Uludag and Yüzüncü Yil. The largest collections are to be found at the METU, Hacettepe and Cukurova Universities, with $2,016,1,760$ and 860 titles respectively.

Interlending in Turkish university libraries

Interlending among Turkish university libraries is an activity which has been largely neglected. A crucial

Interlending and Document Supply, 15 (4), 1987 hindrance to the development of interlending services amongst not only university libraries but all kinds of libraries has been the General Auditing Law, passed in 1927. Under the terms of this Law librarians are personally responsible for any losses from their collections and must reimburse the library from their own salaries. Even though this legal sanction may be overridden most librarians prefer not to take risks.

What is promising is that the 1986 Draft By-Law Concerning the Establishment of University Libraries and Their Services ${ }^{4}$ acknowledges interlending as part of user services and outlines a new by-law to organize and co-ordinate efforts in this respect. This signifies a change of attitude towards interlending services and should result in an increase in interlending traffic between university libraries in the near future.

The present level and nature of ILL activity is revealed by the findings of a recently conducted questionnaire survey of 28 universities of which 15 responded.

Data was collected in the following areas: the number of interlending transactions; the channels used for the delivery of requests and documents; photocopy, telex and telefacsimile facilities of university libraries; union lists of serials; the number of photocopies produced, etc.

Eighty-six per cent of Turkish university libraries either possess, or have access to, photocopying equipment. Only two university libraries, Hacettepe and Uludag possess telex and seven others have access to the telex facilities of the universities to which they are attached. The only university library which has its own telefax equipment is that of Uludag, although another nine have access to such a facility. The Universities of Anatolia, Bilkent, Gazi, Hacettepe and Inönü have no telefax facilities.

Eight of the 15 libraries which responded have either published or computer printout lists of serials. These university libraries are Aegean, Anatolia, Cumhuriyet, Cukurova, Erciyes, Gazi, Hacettepe and METU. The frequency of the union lists they publish varies but most are irregular. HECDOC also produces a list of its serial holdings.

A further development on the listing front followed the First Meeting of the Directors of University Libraries and Documentation Centres, held in Ankara in 1985. There it was agreed that all university libraries should send details of their current serial subscriptions and holdings of back issues to HECDOC. This may facilitate the regular publication of a union catalogue of serials which will include the holdings of all university libraries. ${ }^{5}$ Should HECDOC be able to create a database of serial holdings it will be able not only to supply photocopies from its own stock but also to act as a switching centre for requests which it cannot satisfy. This would be an 
enormous step forward. It was also agreed that in the meantime these lists should be sent to all other university libraries as a first step to streamlining the interlending services. A major problem limiting progress is that many of the individual lists are not up-to-date.

At the moment the use of the ILL services is not great. Of the 15 universities responding to the questionnaire, 2 stated that they never used them and of the remaining 13 , 7 had requested no books in 1985 and 4 no serials. The remaining libraries between them requested from within Turkey only 209 books (89\% success rate) and 541 serials $(95 \%$ success rate). Other types of material were never requested.

Those libraries with the strongest collections, Gazi, Hacettepe and METU, requested least on ILL, perhaps assuming that their poorer colleagues would have little chance of satisfying their needs. Those which made no use of the ILL system tend to be the newly established libraries of Cumhuriyet, Yüzüncü Yil and Erciyes. One anomalous case is that of the University of Istanbul, an old, large, legal deposit library serving the largest student population. It is surprising and inexplicable that it made no use of the ILL system for requesting books.

HECDOC is the most important element in the ILL system, providing $55 \%$ of the satisfied items and already achieving a $50 \%$ success rate. Other university libraries $(21 \%)$ and special libraries $(19 \%)$ supplied the remainder.

The only university library which received interlending requests from abroad was the University of Istanbul. It received 90 requests ( 5 for books, 50 for serials and 35 for microforms) and satisfied 88 (or $98 \%$ ). The library's rich collections of manuscripts and old printed books are obviously an attractive quarry for foreign libraries.

Requests made by Turkish university libraries to foreign libraries numbered 573, of which 499 (87\%) were satisfied. Ninety-six per cent were for serials (satisfaction rate $87.5 \%$ ) and the remainder for books (satisfaction rate $65 \%$ ). Almost $75 \%$ of all international requests were sent to the British Library Document Supply Centre (BLDSC).

Traditional mail systems for transmitting both requests and documents are heavily used by university libraries. The second most frequently used delivery method (for requests only) is the telephone. Three university libraries stated that they transmitted their interlending requests using telex and telefax equipment. No other methods such as courier or shuttle service were reported.

One thing which became evident during the study was that the various libraries have different policies in

Interlending and Document Supply, 15 (4), 1987 relation to charging for ILL requests. Some absorb interlending costs while others pass on the costs to users.

The majority of ILL requests for serials are satisfied as photocopies, although 6 out of 13 university libraries reported that they were unable to provide photocopy services to other libraries.

The provision of photocopies between libraries was a discussion topic at both the First and Second Meetings of the Directors of University Librarians. Arising from the First Meeting was the decision that a standard 'photocopy request form' should be developed by HECDOC and distributed to all university libraries. As a result a substantial increase in the number of photocopies produced by HECDOC is likely to occur.

\section{Conclusion}

Collection development in Turkish libraries is being seriously affected by declining budgets, rising literature prices and a shortage of hard currency. Resource sharing, including ILL, is seen as one way of solving these problems. The full extent of ILL activity is not easy to assess, since the statistics collected by university libraries about their interlending services are scanty, and in some cases it has proved impossible to obtain any statistics at all. What statistics are available indicate that the total number of interlending transactions in Turkish university libraries on both a national and an international level is very low.

There is a tendency for centralized university libraries with strong collections to lend their materials but not to borrow from other libraries. Also there appears to be a strong relationship between interlending transactions of university libraries and the way they organize their collections. Decentralized library systems seem to be more passive in the interlending process.

As time passes HECDOC has been building its reputation as a national serials centre for foreign serials by means of providing photocopies of articles from its own collection.It is also planning to supply photocopies of articles from abroad in the near future.

\section{References}

1. Statistical Yearbook 1985. Paris, UNESCO, 1985, Table 3.10.

2. Tonta, Yasar. 'An interlibrary lending network for sharing of serials collections amongst university libraries in Turkey' (MLib Dissertation, Aberystwyth, 1986).

3. Tuncer, Nilüfer. Yüksekögretim Kurulu Dokümantasyon ve Uluslararasi Bilgi Tarama Merkezi (The Higher Education Council Documentation and International Literature Search Centre). Yïksekögretim Bïlteni, 1986, 1, 33 . 
4. Universite Kütüphanelerinin Kurulmasi ve Hizmetlerine iliskin Yönetmelik Taslagi (The Draft By-Law Concerning the Establishment of University Libraries and Their Services). Ankara, 1986. (Mimeographed)
5. Universite Kütüphane ve Dokïmantasyon Daire Baskanlari (1). Toplantisi (First Meeting of the Directors of University Libraries and Documentation Centres). Ankara, 26-27 September 1985. (Mimeographed)
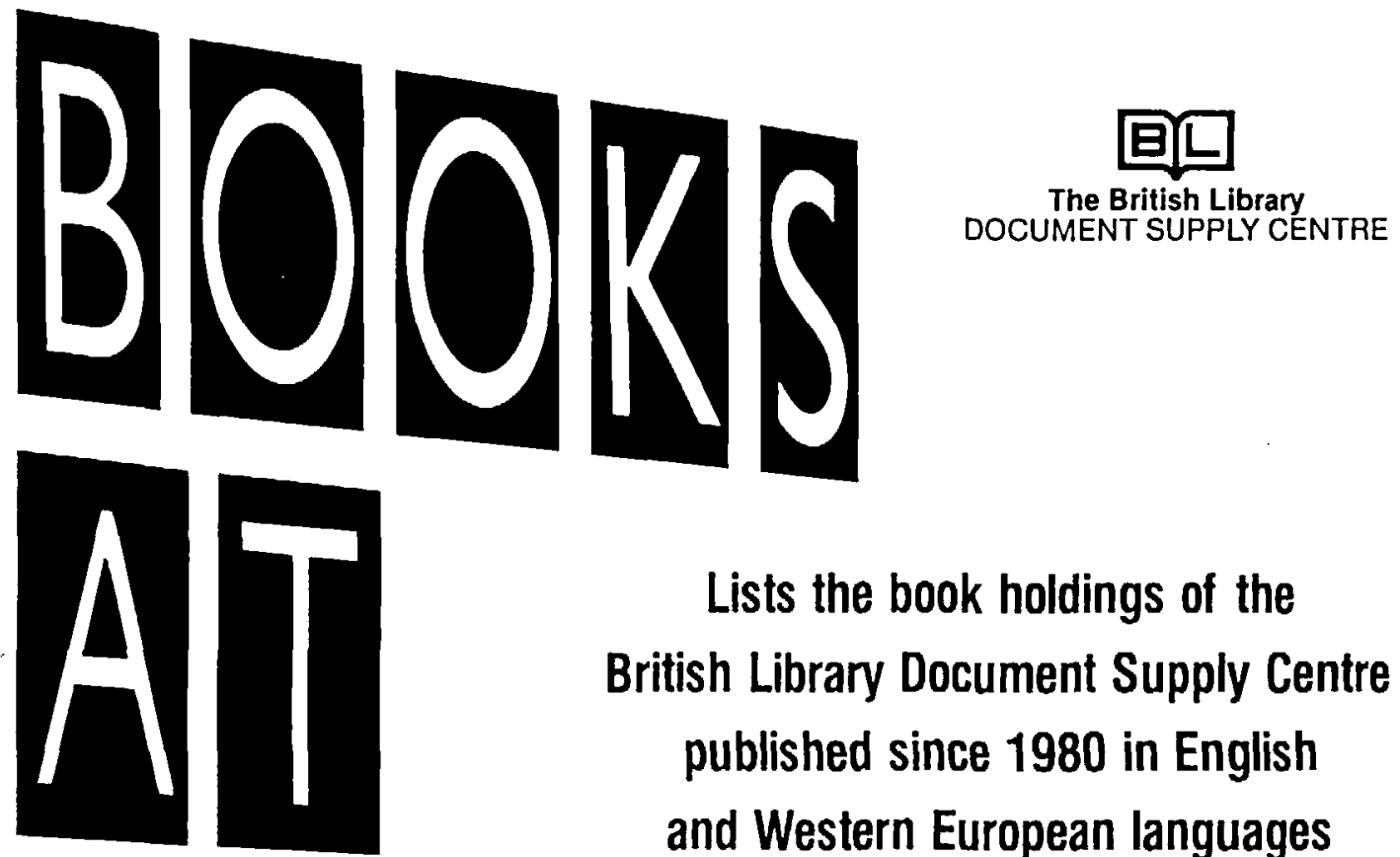

Lists the book holdings of the

British Library Document Supply Centre published since 1980 in English and Western European languages
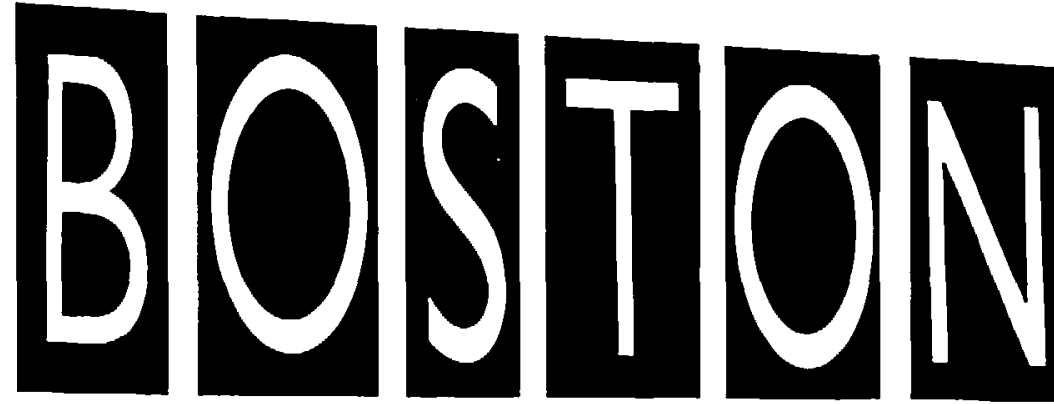
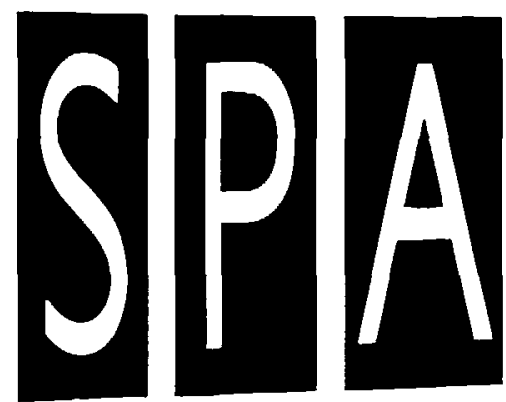

Further cetals can be obtained from Publications Marketing British Library Document Supply Centre Boston Spa - Wetherby

West Yorkshire LS23 780 Ie'eptione Bosion Spa (0937) 843434
- Over 545,000 entries

- All books listed available for loan

- Produced on microfiche

- Cumulated sets

- 5,000 titles added every month

- Entries under title and author 